\title{
DEVELOPMENT OF A TRACEABILITY MODEL APPLIED TO GOAT AND SHEEP MEAT PRODUCTION
}

\author{
Doi:http://dx.doi.org/10.1590/1809-4430-Eng.Agric.v37n5p1062-1072/2017
}

\section{ALAN C. BEZERRA ${ }^{*}$, HÉLITON PANDORFI ${ }^{2}$, RAFAEL M. GAMA ${ }^{2}$, FRANCISCO F. R. DE CARVALHO ${ }^{2}$, CRISTIANE GUISELINI ${ }^{2}$}

\author{
${ }^{1 *}$ Corresponding author. Universidade Federal Rural de Pernambuco - Unidade Acadêmica de Serra Talhada/ Serra \\ Talhada - PE, Brasil. E-mail: cezaralan.a@gmail.com
}

\begin{abstract}
The goat and sheep meat producer chain has developed in last years, thus, it is imperative to organize and structure the supply chain and to adopt reliable policies for products' traceability, as a tool to achieve these requirements. The study aimed to make a management program with a traceability model for goat and sheep meat production, with emphasis on ensuring product origin and management practices' transparency at the animal production unit. For this purpose, it was made a reference model in order to emit an origin certificate which, in turn, provides specific information concerning the final product from each unit. Secondly, the program was developed using Hipertext Preprocessor (PHP) technology and as for the Database Management System, it was used MySQL. The schematic model proposed meets the requirements of a traceability system for goat and sheep meat. Furthermore, the program can work as a tool for farm management, by reports and real-time remote access to information.
\end{abstract}

KEYWORDS: goat and sheep meat production, traceability, food safety, management system.

\section{INTRODUCTION}

At the beginning of the $21^{\text {st }}$ century, goat and sheep meat consumption has significantly increased among the main consumer centers in Brazil, according to Barreto Neto (2010), which motivates the necessity of funding and organization so that the activity reaches desirable standardization and quality for more demanding markets. Partnership among different segments of goat meat production may assist livestock improvement, marketability and extension of new technologies (Teixeira et al., 2013).

Due to production lines' and governments' pressure, traceability has emerged as an excellent tool of these new demands from the consumers market (Nicoloso \& Silveira, 2013), by allowing the tracing of records, activities and location of a product through information previously registered and identified. Additionally, it allows the producer to respond to threats of food security, to record production practices, to ensure that the production meets governmental requirements and to analyze logistics and production costs (Tharkur et al., 2011).

Regarding reference models for traceability, some studies have modeled several supply chain, in which all important information was listed and structured in a logical sequence. Qian et al. (2012) developed a Wheat Flour Milling Traceability System (WFMTS), that incorporate 2D barcode and radio frequency identification (RFID) technology, and they also validated the system in a wheat flour mill in China. While Feng et al. (2013) proposed a conceptual model of cattle/beef traceability system, implemented a traceability system and evaluated this system in sample supply chain. Hu et al. (2013) developed a traceability system model on vegetables supply chain based in Unified Modeling Language (UML) and discussed how to implement this model in the supply chain. In the other hand, regarding the programs applied to management and traceability, Gogliano Sobrinho et al. (2010) and Porto et al. (2009) modeled system focused on wine chains' management and traceability.

\footnotetext{
${ }^{2}$ Universidade Federal Rural de Pernambuco/ Recife - PE, Brasil. 
The current study was performed with the objective to develop a traceability program for goat and sheep meat production, with emphasis on ensuring product origin and management practices' transparency at the animal production unit.

\section{MATERIAL AND METHODS}

In order to perform this study, it was applied web-based techniques, as a premise to visualize the activities of zootechnical exploitation in a safer real-time mode. Three phases for the development of the program were performed: bibliographical survey of information regarding goat and sheep meat production unit, elaboration of a schematic model and systematization of the computer program.

The first phase comprised bibliographical survey about the main management techniques for goat and sheep meat in Brazil, in order to determine the necessary variables for records, as well as their functions, services and utilities, according to recommendations of Sandoval Jr (2011); Santos et al. (2011); Pizzani et al. (2012); Zanette \& Neumann (2012); Holanda Júnior \& Sousa Neto (2013).

The second phase consisted on the elaboration of the schematic model for goat and sheep meat unit, based on the information collected on the previous phase. It was used as reference the guidelines of animal management and the proper legislation used for the production of goat and sheep meat. This model was generated based on the study of Opara (2003), which assumed the six main elements for the development of a marketable production system with traceability (Figure 1).

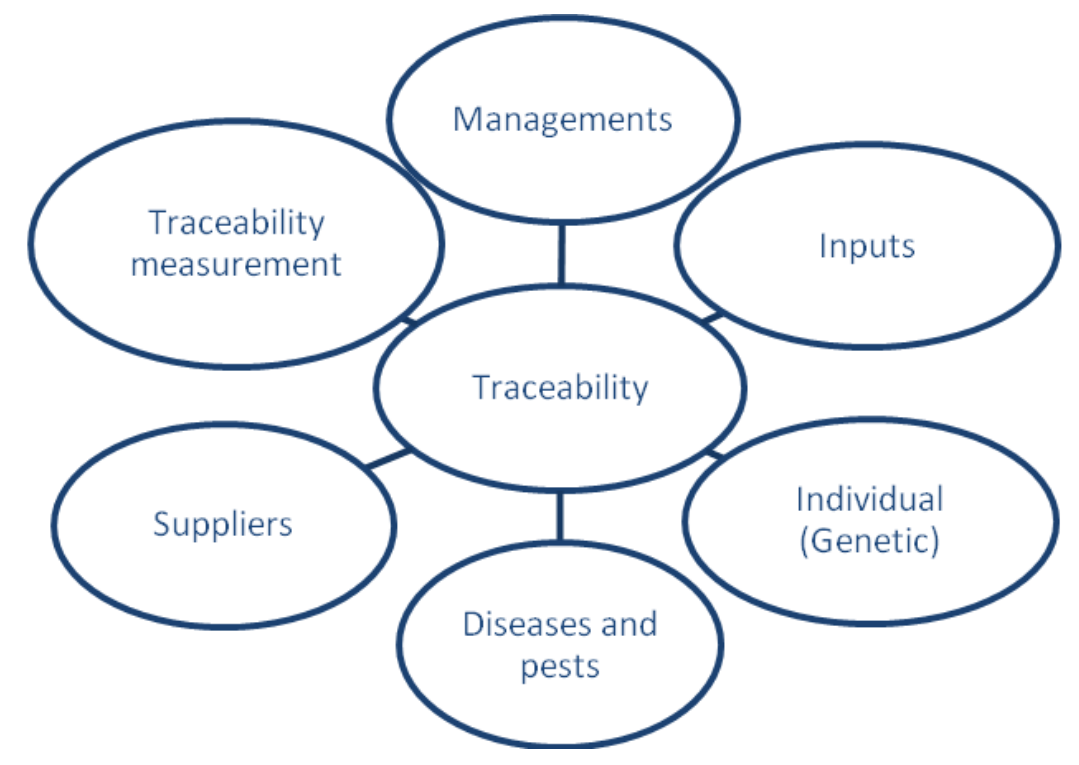

FIGURE 1. Description of elements from a traceability program. Adapted from Opara (2003).

After the bibliographical survey phase and the development of the schematic model, it was initiated the web-based programming, so that every operator could access it remotely without the need of physical presence in a given location. This characteristic is important because it allows the mobility of operators and managers of the properties, as the information can be accessed within or outside the production unit.

The program was installed in a web server, with the Database Management System in Structured Query Language (MySQL) and programming language in Hipertext Preprocessor (PHP). It was chosen to use the MySQL for its reliability, sturdiness, gratuity and portable in different platforms, besides its easier interaction with PHP (Porto et al., 2009; Gogliano Sobrinho et al., 2010). 


\section{RESULTS AND DISCUSSION}

Figure 2 shows the schematic model proposed for goat and sheep meat production. The beginning comprises the production of necessary feedstock and inputs, in which every aspect regarding the products are surveyed. Subsequently, the different managements used on animal production were taken into account, as well as identification activities, records and tracking of every production cycle steps. Every data was registered in a database so that they could be accessed and allowed the generation of pertinent information regarding technical reports, used in the accompaniment of the activity and in the support of decision making.

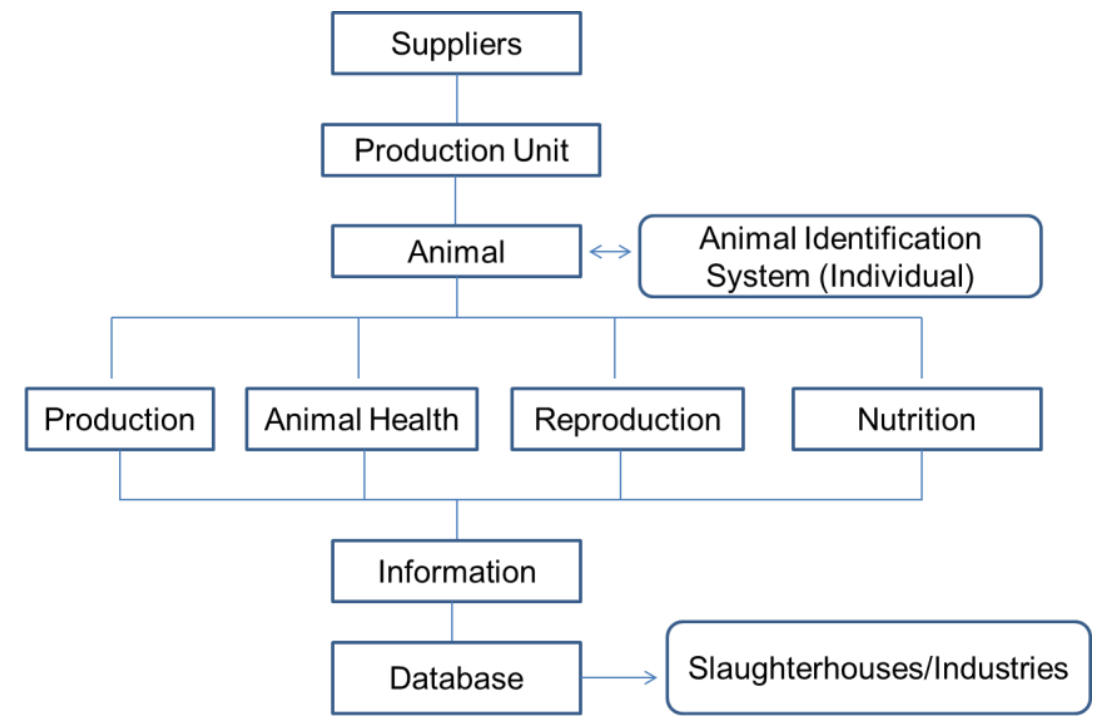

FIGURE 2. General model for goat and sheep meat traceability.

Thus, the following items were supported by the proposed model: breed, feeding origin and nature, antibiotic-free food and growth promoters, responsible use of therapeutic antibiotics, reproduction program, animal health aspects and good veterinary practices.

It is possible to observe the details of the proposed model, as well as the recording of managements throughout the animals' life-histories (Figure 3). It can be highlighted that the model has 3 steps, in which the first refers to the general view of the model, comprising information about the production unit and the producer; at the second phase, it was provided information about the animals; while, at the third step, the main management practices and production indices were provided, through the emission of a managerial report of each production unit.

The principles which were used as guides in the elaboration of this model were simplicity and objectivity. This allowed information management in a safer and reliable manner, with the possibility of adapting for different conditions and users' profiles. The generated information in each element of the traceability were used as clear and objective evidences of what was performed, which allows real-time remote connection of the product to its origins, even if the production system involves different in-series and inter-related processes.

The proposed model allowed information registration using a computer program, which enabled the traceability throughout the production cycle, so that the production record could be evaluated, guaranteeing the transparency of each production unit. 


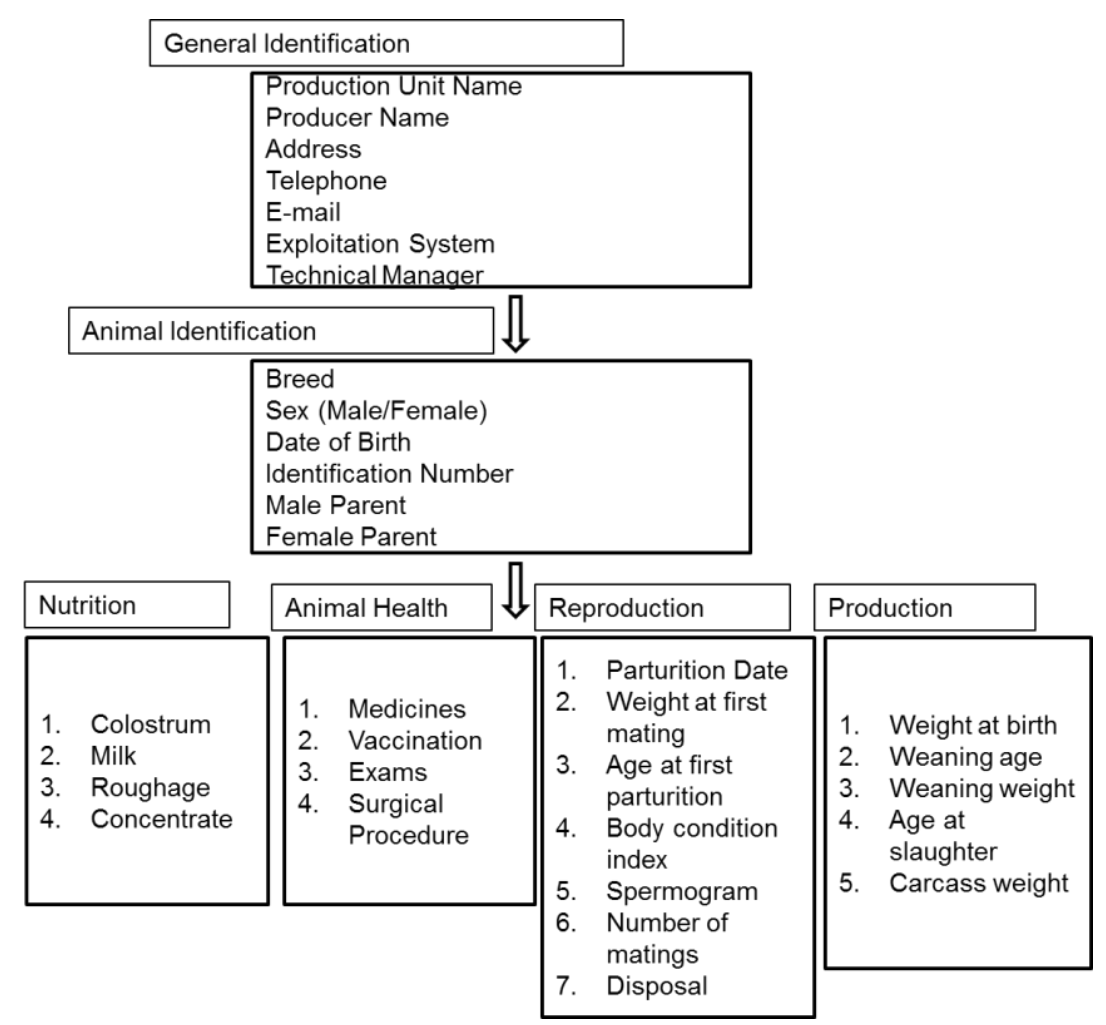

FIGURE 3. Information diagram for goat and sheep meat traceability.

By having the data collected throughout the production line cycle, some zootechnical and managerial indices were possible to be obtained. These indices have a great importance for the property because the proper management of animal production enables the improvement of the producer's competitiveness in the market. Production management encompasses general aspects of the flock, from general management practices and zootechnical bookkeeping to reproduction, animal health and nutrition management.

Therefore, the following zootechnical indices were obtained: birthrate, fertility rate, reposition rate, parturition interval, post-partum interval, weight gain and weight at slaughter.

The developed computer program, based on the schematic model of production traceability, may be used in several operational systems and hardware, as it is based on a web platform. On account of being a system of association and/or cooperation among producers, the use of internet as a channel among the participants was important to the interaction among participants, which characterizes small to medium producers.

The systematization of the model on a computer basis bestowed safer data and enabled the transparency of the production line to the users. As it is well highlighted by Porto et al. (2009), in affirming that the consumers may know if the product was produced under quality standards or if it was produced under some limitations. Apart from that, the system also enables a more precise accompaniment of the performed activities in each production unit and the determination of production indices, which may assist the company management.

Thus, every piece of information provided by the program was stored in a database and the registered users can access their respective information (Figure 4). Within the production reality, the developed system may integrate different sectors of the property to external agents. 


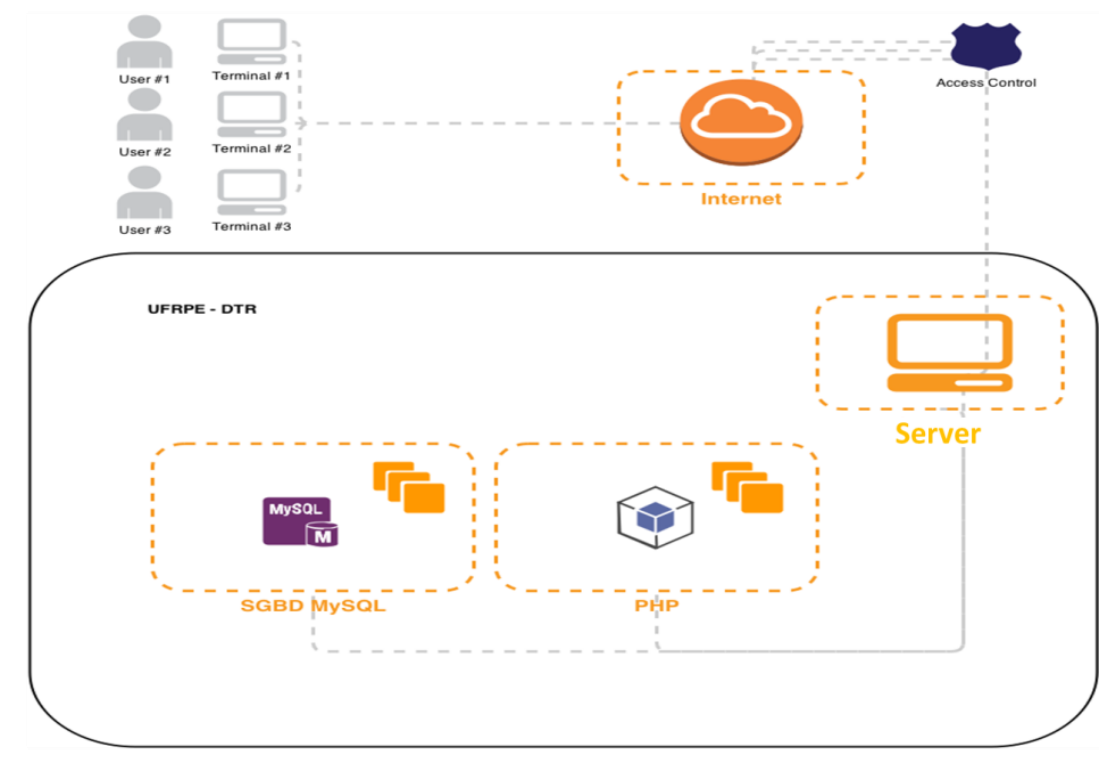

FIGURE 4. System's architecture.

In order to do so, the requirements to use the system are internet access and a web browser (Internet Explorer, Chrome, Mozilla Firefox, among others). The initial screen of the program, in which the user types his name and password, can be seen in Figure 5. Then, the user signs up to the system's manager who, in turn, verifies some initial property's information and check their veracity.

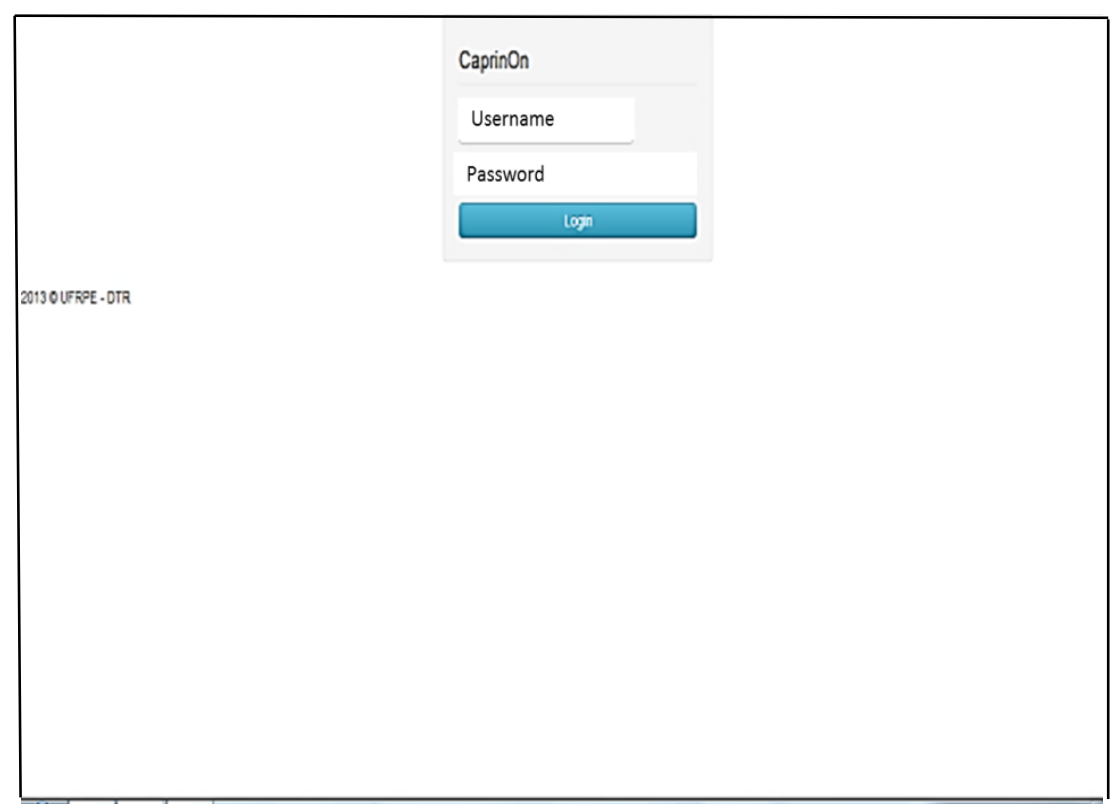

FIGURE 5. Users and properties' registration.

After filling up the information required, the user is directed to a new window with several information options (Figure 6). In this part, the user might choose among several options, such as: farms, users, animal history, drugs, feeding, suppliers, technicians and panels (reports). The user may insert each production unit's information which is destined to the production of goat and sheep meat. 


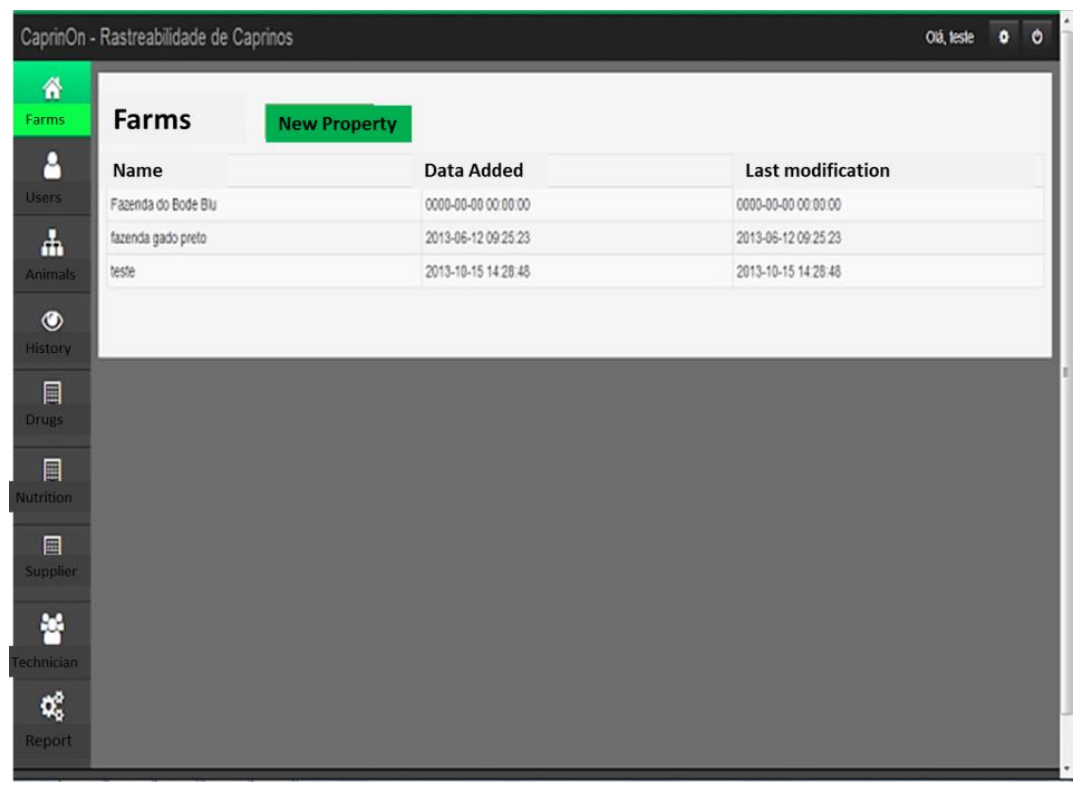

FIGURE 6. Registered properties list.

On the screen "Users" it is possible to visualize every registered user to the account and who will be able to perform changes and insertions of the collected data in each production unit (Figure 7). In this list, it is observed the user's name, email, identification and property to which the user is referred to. In order to register a new user, one must simply click on "New User" and fill in the required information.

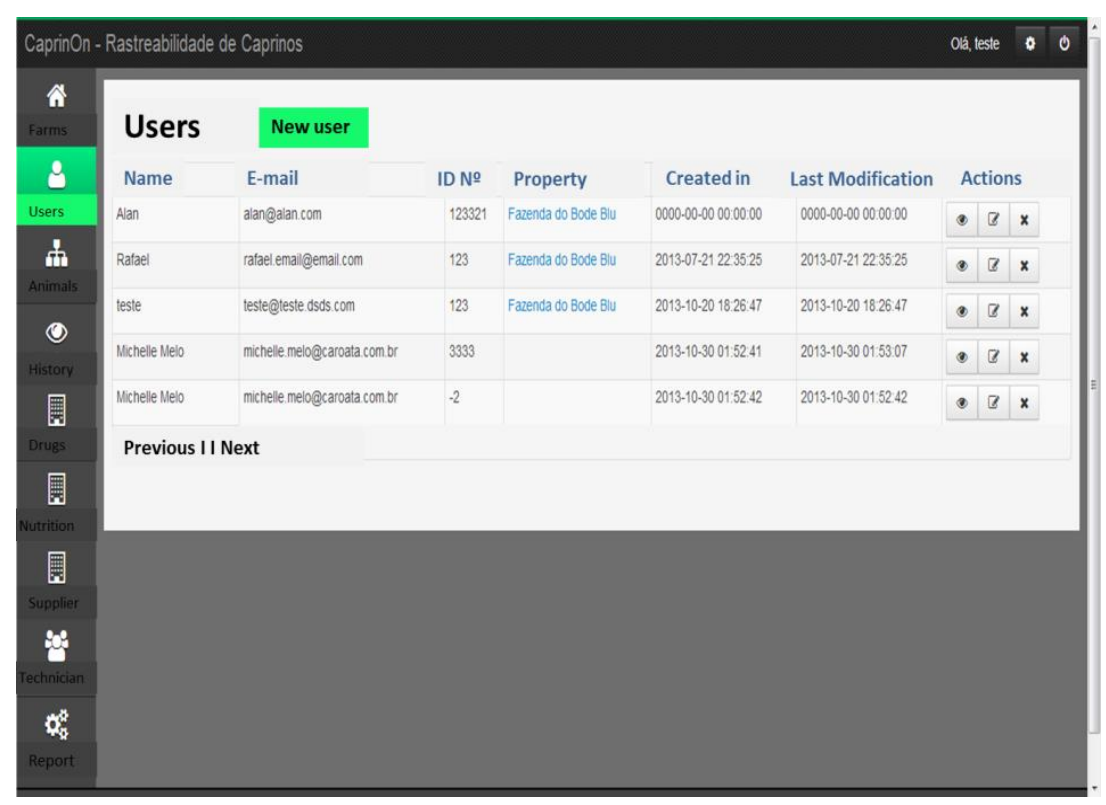

FIGURE 7. Users' list.

After that, in the "Animals" tab it is possible to verify the animals' list in the farm (Figure 8). It is noteworthy that the information on animal identification, such as register number and/or microchip number, is visualized. In the last column, named "Actions", it is possible to detail each animal, by clicking on the first symbol (selected animal data), second symbol (edit the information) and the last symbol (excludes the animal from the list). These icons lead the user to the "History" tab. Clicking on the upper icon "New Animal", the user can add a new animal to the list, where it will be required the identification and microchip numbers, birth property, sex, date of birth, breed, parents' identification. 


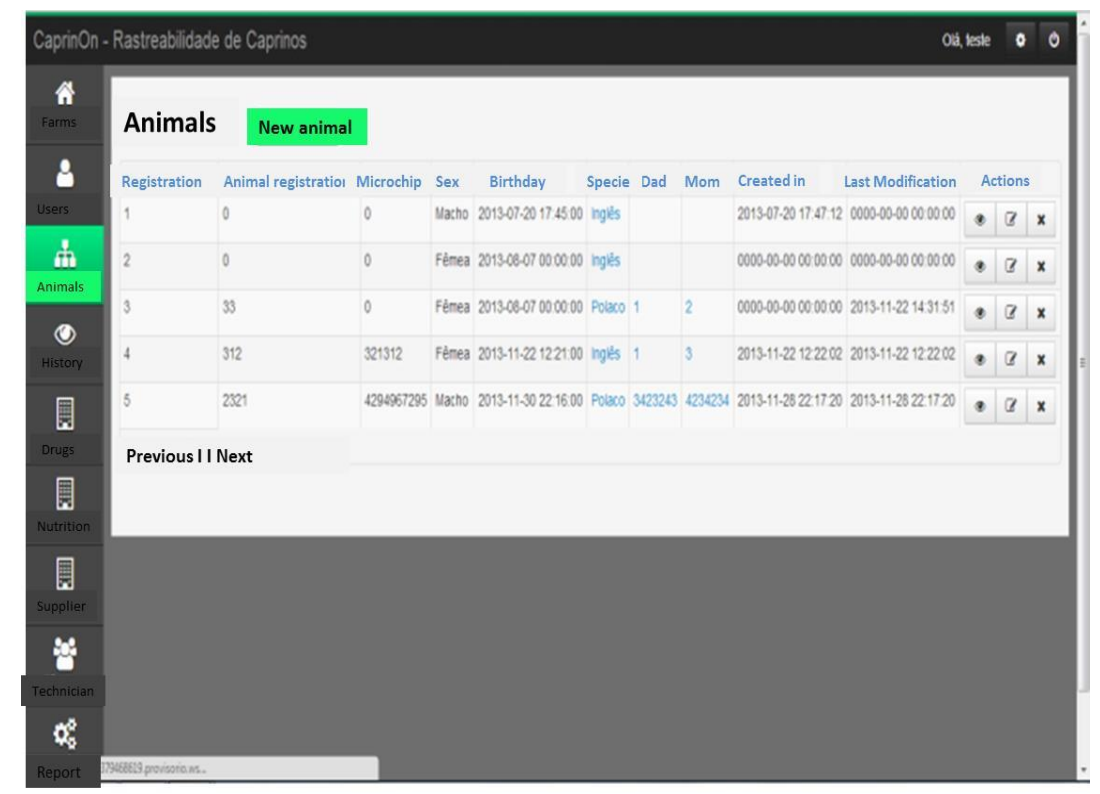

FIGURE 8. Animal, identification and respective management's registration.

The "History" of the animal may be accessed by the icon located at the second column to the left of the program or through the detailed information of each animal, as cited before (Figure 9). It is possible to access key information of the animal, such as: weight at birth, weight at slaughter, date of slaughter or death, among other.

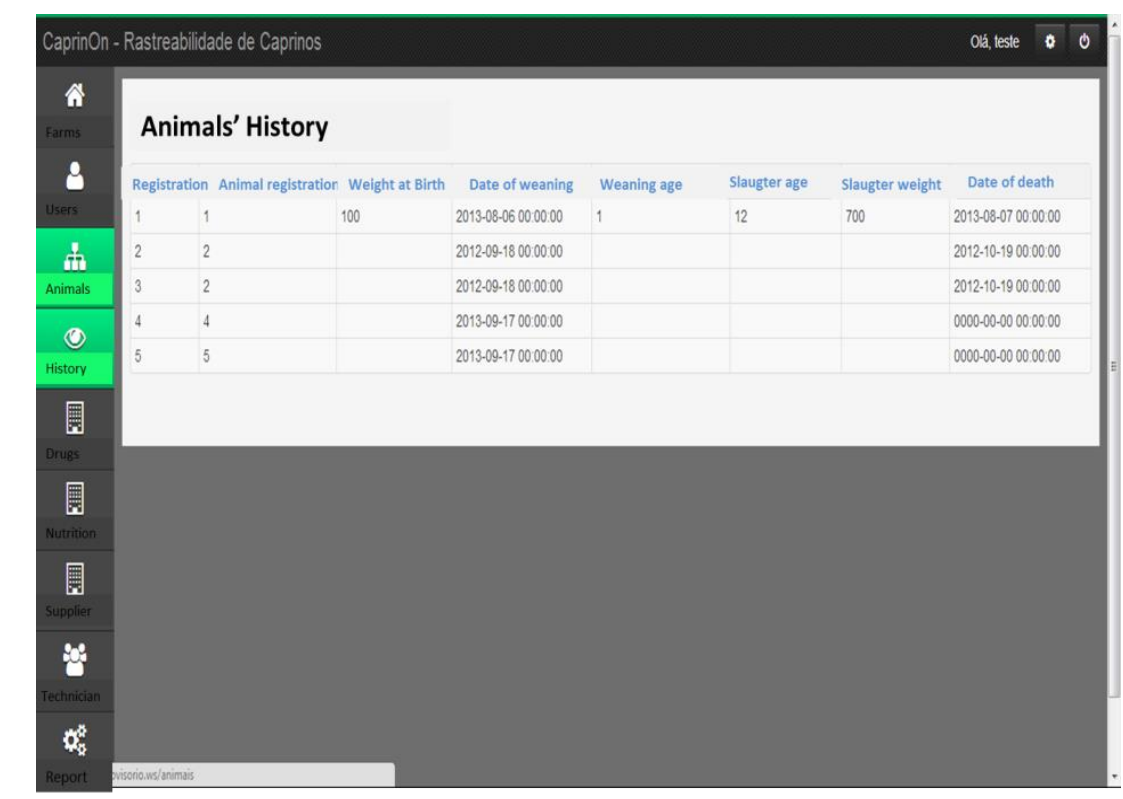

FIGURE 9. Animal's history data.

On the tab "Drugs", it can be observed every medicine provided at the property (Figure 10). It can be verified the name, registration number, date of application, supplier, due date and interval among observations. It is also possible to add a new drug by clicking on the upper icon. The window to insert a new drug requires the aforementioned information. 


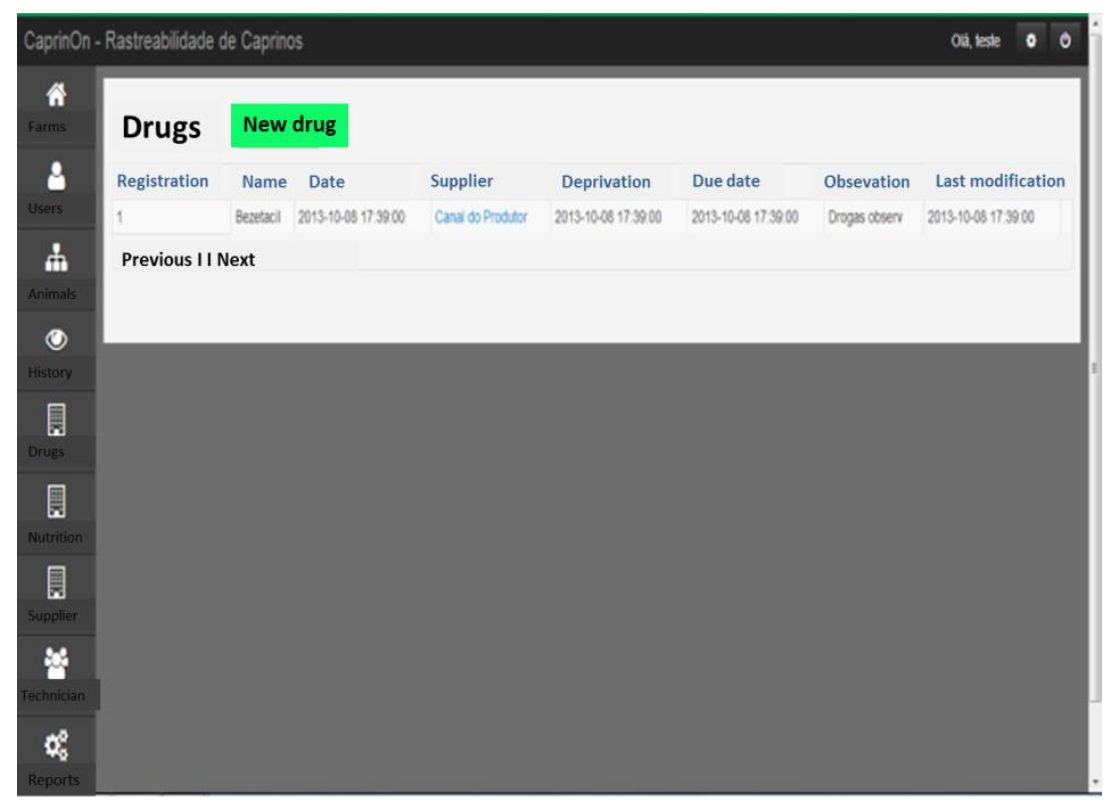

FIGURE 10. Registration for medicines, vaccines, antibiotics, acquisition and period of deprivation.

The tab "Nutrition" lists all the information concerning the products used to feed the animals (Figure 11). It is possible to categorize the food into roughage or concentrate; or if the animal has drunk milk. By clicking "New nutrition" it is possible to insert new information for the animals.

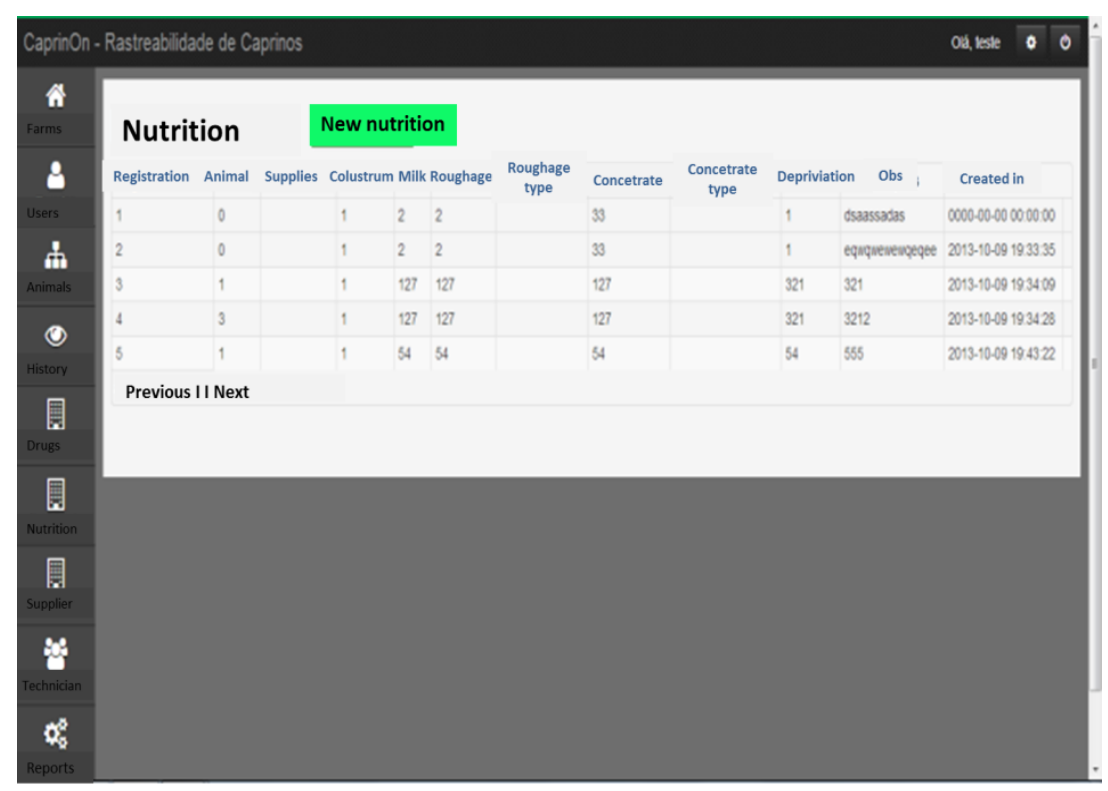

FIGURE 11. Animal feeding information.

On the icon "Suppliers", it can be observed information regarding the companies which provide the products to the property. It is provided the complete list of companies, with their names and their registration of legal entities (CNPJ) (Figure 12). In order to insert a new supplier, we just needs to click on "New Supplier". 


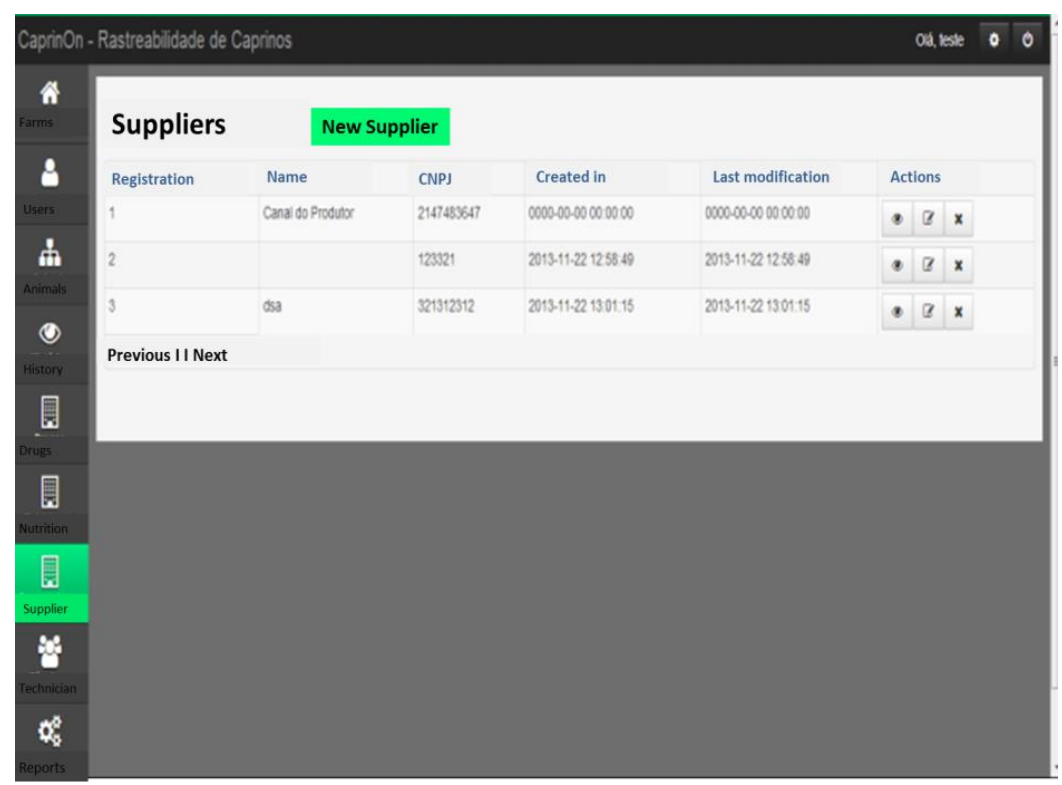

FIGURE 12. Suppliers' registration.

The tab reserved for "Technicians" shows the complete list of the technicians who work at the farms, their names and attributions (Figure 13). To add a new technician, it is necessary to click on "New Technician" and input the aforementioned data.

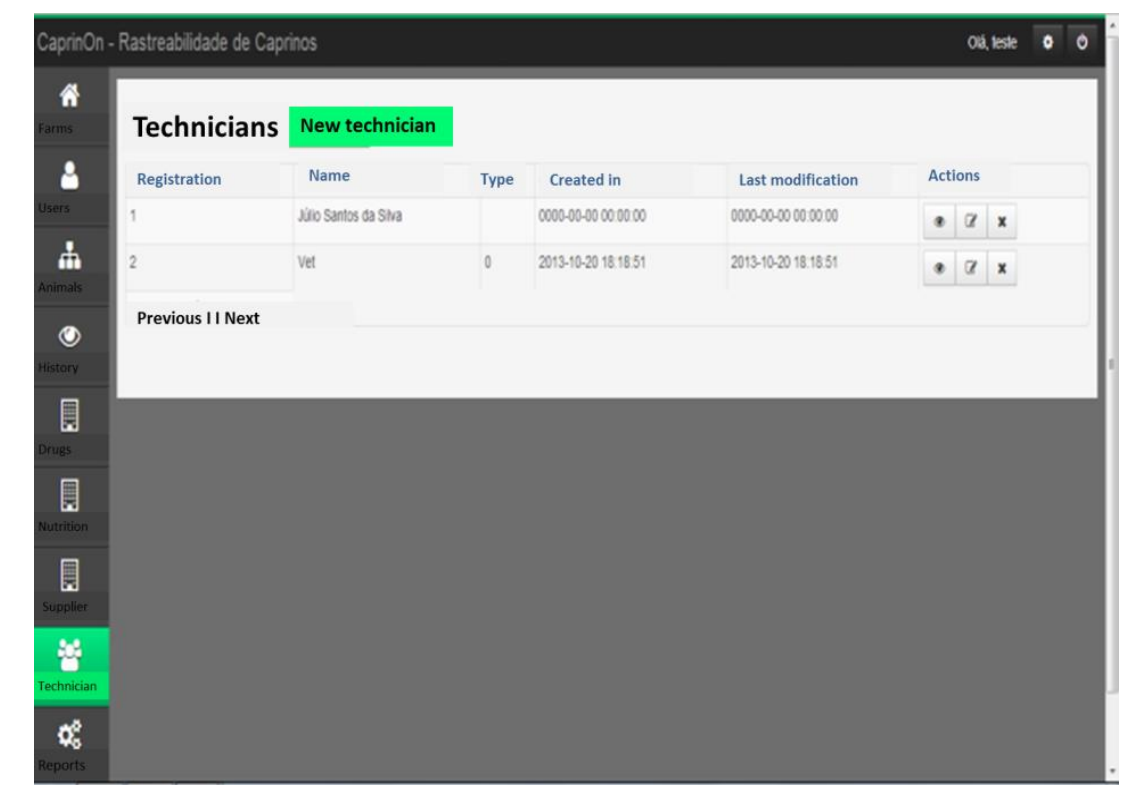

FIGURE 13. Technicians' registration involved in the production system.

The last icon provided by the program is "Reports" (Figure 14). While in this tab, the user can visualize some graphics which will be part of the technical report of the property, such as: annual fertility rate, death rate, slaughtered animals, newly born animals and birth rate. 


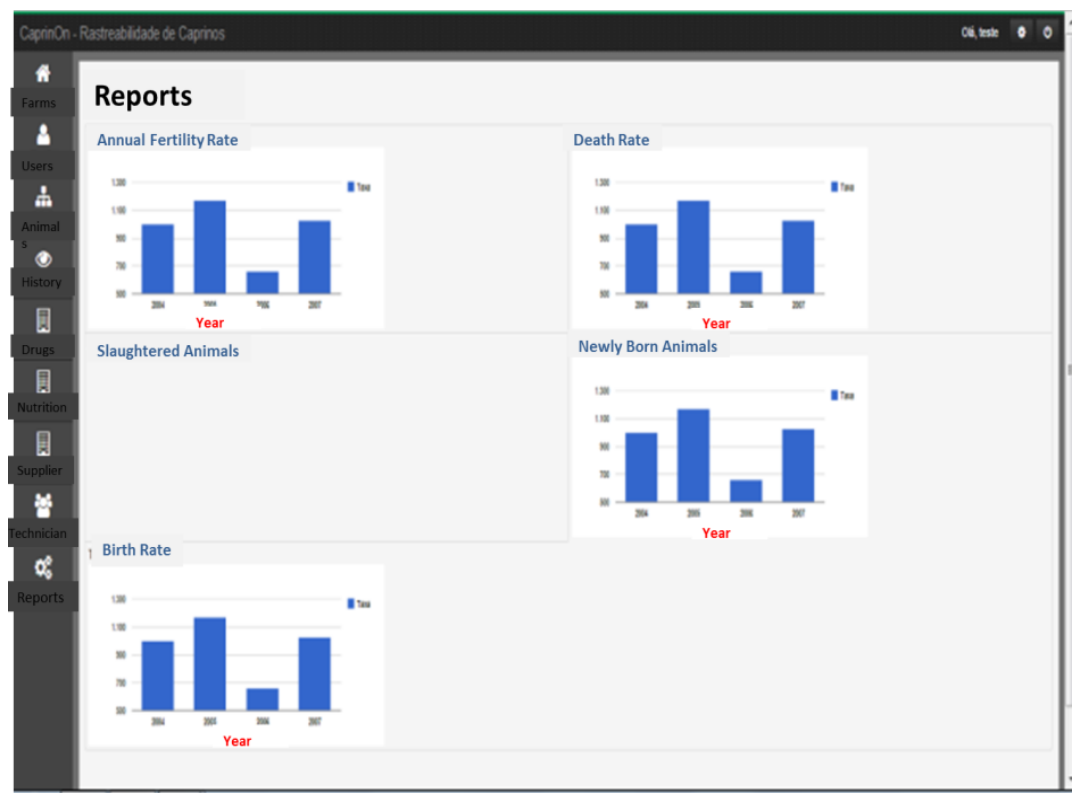

FIGURE 14. Emission of managerial reports.

All of these resources are very important and helpful for the productive chain of goat and sheep meat. The producers will be able to access information and obtain reports on their properties at any time and place. The expansion of the program is possible so that other elements of the production chain may access information via key-code, which has to be informed previously. Thus, the consumers and other companies will be able to know the way the animals were produced, which, in turn, guarantees a greater transparency of the production system. Several system have already been used for this purpose, which allows transparency and agility (Porto et al., 2009; Gogliano Sobrinho et al., 2010; Qian et al., 2012; Feng et al., 2013; Hu et al. 2013).

\section{CONCLUSIONS}

The proposed schematic model meets the requirements of transparency needed for the traceability of goat and sheep meat; as well as functioning as a tool to improve producers' management, through reports and real-time remote access to information.

This proposal of systematization of goat and sheep meat production line may be expanded to other elements within the production chain, as well as to other sectors, such as goat and sheep dairy production.

\section{REFERENCES}

Barreto Neto AD (2010) Posicionamento estratégico do setor de carnes de caprinos e ovinos no mercado de carnes brasileiro. Revista Tecnologia \& Ciências Agropecuárias 4(4):81-85.

Feng J, Fu Z, Wang Z, Xu M, Zhang X (2013) Development and evaluation on a RFID-based traceability system for cattle/beef quality safety in China. Food Control 31(2):314-325. Available: http://www.sciencedirect.com/science/article/pii/S0956713512005749. Accessed: Mar 19, 2015.

Gogliano Sobrinho O, Cugnasca CE, Fialho FB, Guerra CC (2010) Modelagem de um sistema de informação para rastreabilidade na Indústria do vinho baseado em uma arquitetura orientada a serviços. Revista Engenharia Agrícola 30(1):100-109.

Holanda Júnior EV, Sousa Neto JM (2013) Evolução das Práticas de Manejo dos Sistemas de Produção de Pequenos Ruminantes no Semiárido Nordestino. Revista Científica de Produção Animal 15(1):77-89. Available: http://www.ojs.ufpi.br/index.php/rcpa/article/view/2143/1499. Accessed: Feb 14, 2015. 
Hu J, Zhang X, Moga LM, Neculita M (2013) Modeling and implementation of the vegetable supply chain traceability system. Food Control 30(1):341-353. Available: http://www.sciencedirect.com/science/article/pii/S0956713512003696. Accessed: Feb 14, 2015.

Nicoloso C, Silveira V (2013) Rastreabilidade Bovina: Histórico e Reflexões Sobre a Situação Brasileira. Revista em Agronegócio e Meio Ambiente 6(1):79-97.

Opara LU (2003) Traceability in agriculture and food supply chain: A review of basic concepts, technological implications, and future prospects. Journal of Food, Agriculture \& Environment 1(1):101-106.

Pizzani L, Silva RC, Bello SF, Hayashi MCPI (2012) A arte da pesquisa bibliográfica na busca do conhecimento. Revista Digital de Biblioteconomia e Ciências da Informação 10(1):53-66.

Porto LFA, Lopes MA, Zambalde AL (2009) Desenvolvimento de um sistema de rastreabilidade aplicada à cadeia de produção do vinho. Ciência e Agrotecnologia 31(5):1310-1319.

Qian JP, Yang XT, Wu XM, Zhao L, Fan BL, Xing B (2012) A traceability system incorporating 2D barcode and RFID technology for wheat flour mills. Computers and Electronics in Agriculture 89(10):76-85.

Sandoval Jr P (coord) (2011) Manual de criação de caprinos e ovinos. Brasília, Codevasf. 142p.

Santos TC, Peña-Alfaro CE, Figueiredo SM (2011) Aspectos sanitários e de manejo em criações de caprinos e ovinos na microrregião de Patos, região semiárida da Paraíba. Ciência Animal Brasileira 12(2):206-212.

Teixeira IAM, Gomes RA, Castagnino DS, Figueiredo FODM (2013) Inovações tecnológicas na caprinocultura. Revista Brasileira de Saúde e Produção Animal 14(1):104-120.

Tharkur M, Martens B, Hurburgh CR (2011) Data modeling to facilitate internal traceability at a grain elevator. Computers and Electronics in Agriculture 75(2):327-336.

Zanette PM, Neumann M (2012) Containment as "tool" to increase in the production and quality of the meat of sheep. Ambiência 8(2):415-426. 